\title{
Algunas consideraciones sobre la sociedad de gananciales
}

\author{
Iosć Luis González - Sitárez.
}

En toda sociedad conyugal legalmente constituida, nace simultáneamente con ella una sociedad de bienes que, por su carácter de aprovechamiento comin por los cónyuges, recibe el nombre de socieclad de Gananciales.

Esta sociedad que constituye nuestro régimen único de bieres on el matrimonio. a pesar de su aparente similitud, no puede ni debe confundirse con una sociedad ciril (contrato) ni mucho meros comercial. Sin embargo, sítiene personería juridica diferente de la de 1;s cónyuges. En ella se mueven con vida propia determinada masa re bienes que suponen un patrimonio específico, al lado de los otros restantes patrimonios propios de los cónyuges, originarios éstes de aiquél.

En efecto, el artículo 176 establece claramente que el matrinusio da vida a una sociedad entre marido y mujer. Esta sociedad a tenor del mismo articulo es impuesta por la ley; su duración depende de la vida en común de los cónyuges, (art. 199): la administráción de los bienes de la sociedad está encomendada por ley al esposo, (art. 189) : razones estas que la diferencia de la sociedad civil y que impiden asimilarla a ella.

Motivo de viejas discusiones doctrinarias ha sido este aspecto de la sociedad gananciales: ¿Es ella una sociedad civil? Planiol y Riper así como Foignet, opinan por la tesis negativa. Sánchez Román, Valverde y de Diego, tratadistas españoles, se inclinan por la afirmativa siguiendo el criterio del Código Civil español que en su ar: 1395 establece que las reglas del contrato de sociedad regiran en defecto de ias de la sociedad de gananciales. De acuerdo con este últino criterio, Rùggiero en su magnífico texto "Instituciones de Derecho Civil", ex- 
pone con evidente exageración que los cónyuges en el matrimonio están impulsados por el afán de ganar dinero con fines a dejar una cuantiosa herencia a sus descendientes. Prueba de ello - añade-- es el apreciable aumento del capital inicial de la sociedad al liquidarse esta. Para este autor la sociedad conyugal, es pues una sociedad de Incro.

Evidentemente la sociedad de gananciales no es una sociedad civil ni comercial y ello se desprende del articulado legal de nuestro código, pero si puede afirmarse que su caracter de sociedai es real y legalmente aceptable.

Sociedad es en lo que supone unión de dos personas. Lo es también en cuanto aportan bienes para un fin común. Tiene su estatuto impuesto por la ley y ella es inscrita en su Registro respectivo. Pero pierde su carácter civil o comercial en su propia naturaleza especialisima. donde el interés personal es supeditado por un interés ético superior, que el Estado resguarda, legisla y orienta hacia fines nomles de propagación de la especie humana.

Como sociedad que es, la sociedad de gananciales tiene una personería diferente de los cónyuges que la integran y ello puede verse a través clel articulado legal.

En el art. 176 queda establecida la sociedad con su patrimonio específico. La formación de bienes para la sociedad sin afectar los bienes de los cónyuges está indicando la existencia de una nueva personaliclad cconómica, de un ser social independiente de los conyiges; en el art. 188 se le encomienda al marido la administración de estos bienes que aparecen entmerados en el art. 184 y en el art. 189 se cstá reconociendo que las facultades administrativas del marido no pueden excederse de una administración regular, es decir, que el marido 110 es titular de sus propios bienes, esto es de los comunes. En el art. 196 se prescribe la afectación de los bienes de la sociedad a sus propias deudas.

Adviertase además que la facultad cle cada cónyuge de disponer de sus bienes propios, establecida en el art. 178, da a los bienes comunes una fisonomía propia como patrimonio sobre el cual -durante la vida matrimonial - no cabe la intervención de los cónyuges at título de propietarios; no puede pues hablarse de copropiedacl. Esta solo surge cuando la sociedad conytıgal ha concluído, procediéndose entonces a delimitar el patrimonio de la sociedad y a establecer. el alcance económico de cada cónyuge.

En realidad la personería propía de la sociedad de gananciales es necesaria para los fines que, desde el punto de vista económico, se persigue en el matrimonio.

El régimen de la sociedad de gananciales permite que se con- 
serve el patrimonio de cada cónyuge, aun dentro de la vida matrimonial y que las cargas que han de soportar los esposos sean subvenidas por el aporte comín del producto de sus actividades y de los irutos que den sus bienes propios. De esta manera, el sostenimiento del hogar tiene una fuente segura de ingreso asegurada en su desenvolvimiento por el aurorte inicial y continuado de cada cónyuge a la jornacion del patrimonio común; lo que envuelve en cierta furma un desprendimiento, a más bien an desplazamiento de determinados bienes cuya propieclad pasa de manos de cada cónyuge a manos de la sociedad. Esta con su patrimonio atiende sus propias necesidades bajo la hábil administración del marido, controlada por la mujer a tenor de los dispuesto en el art. 189, a la manera del control de un socio sobre los bienes que tiene en la sociedad a la que pertenece. De la administración más o menos sabia del patrimonio de la sociedad, podrá luego haber o no ganancias, hecho este que califica la sociedad como "de gananciales".

El que ninguno de los dos cónyuges pueda disponer a su antojo de los bienes de la sociedad, garantiza la economía de la misma, y aunque el marido tenga en sus manos dos patrimonios: el suyo propio y el de la sociedad, éste último lo tiene a título de administrador, con la severa medida de cobrarse su propio patrimonio, a la disolución de la sociedad, en último lugar, lo que en buena cuenta está aclarando la diferencia de patrimonios, base de la diferencia de personalidad social.

La existencia de una sociedad distinta de los cónyuges con patrimonio especifico, suscita otro aspecto de no poca importancia: el de la trinidad de patrimonios.

Para comprenderlo hay que elevarse del concepto especifico de la sociedad de gananciales al concepto genérico de sociedad conyugal, ya que el patrinonio común con su titular, ocupa integramente el campo de la sociedad de gananciales. No caben dentro de ella los cónyuges con sus respectiros patrimonios. Ellos y estos hay que enfocarlos desde el punto de rista de la sociedad conyugal

En relación con este aspecto cabe recordar la doctrina moderna del patrimonio que representa éste como una universalidad de bienes independiente de la persona - en concepto abstracto - en contraposición con la doctrina clásica que sólo reconoce un solo patrimonio en la persona. único $\epsilon$ indivisible con ella.

La doctrina moderna responde mas a la realidad en general y a la realidad en particular de la sociedad conyugal.

El articulado de nuestro código establece tres clases de bienes: bienes propios de la mujer: bienes propios del marido y bienes comunes. Cada uno de estos bienes está sujeto a la disposición de sus respectivos titulares, siendo el representante de la sociedad el mari- 
do. Cada calidad de bienes representa una universalidad económica independiente, donde puede $\mathrm{y}$ en efecto hay, pasivo y activo aplicables tan solo a sus respectivas masas de bienes.

Los bienes propios de la mujer, como los mismos del marido caen bajo la exclusiva administración y disposición de ellos, y las deudas que contraigan se harán efectivas en sus respectivas masas de bienes. (Art. 178).

Suponiendo que los bienes comunes se bastaran a si mismo, en nada se perjudicarían los bienes propios de cada cónyuge, los que en tanto no los requiera êt sostenimiento de la familia, pueden ser dispuestos a voluntad por cada cónyuge. Así también se desprende de las presunciones establecidas en los arts. 185, 186 y 187. Y queda ratificado este concepto al quedar establecido en el art. 201, la liquidación por patrimonios y la copropiedad de los cónyuges sobre los bienes comunes, efectuada la liquidación de la sociedad conyugal, previo inventario judicial para delimitar el alcance de cada patrimonio.

Por último, los arts. 175 y 198 independizan en cuanto la responsabilidad que cabe a cada cónyuge por deudas o por actos ilícitos, sus respectivos patrimonios: y los arts. 166, 169, 190, 191, 192 y 193 están indicando la independencia patrimonial de la sociedad que puede ser administrada excepcionalmente por la mujer en los casos señalados por ley. 